\title{
DOMINIC BRYAN
}

AND S. J. CONNOLLY

WITH JOHN NAGLE
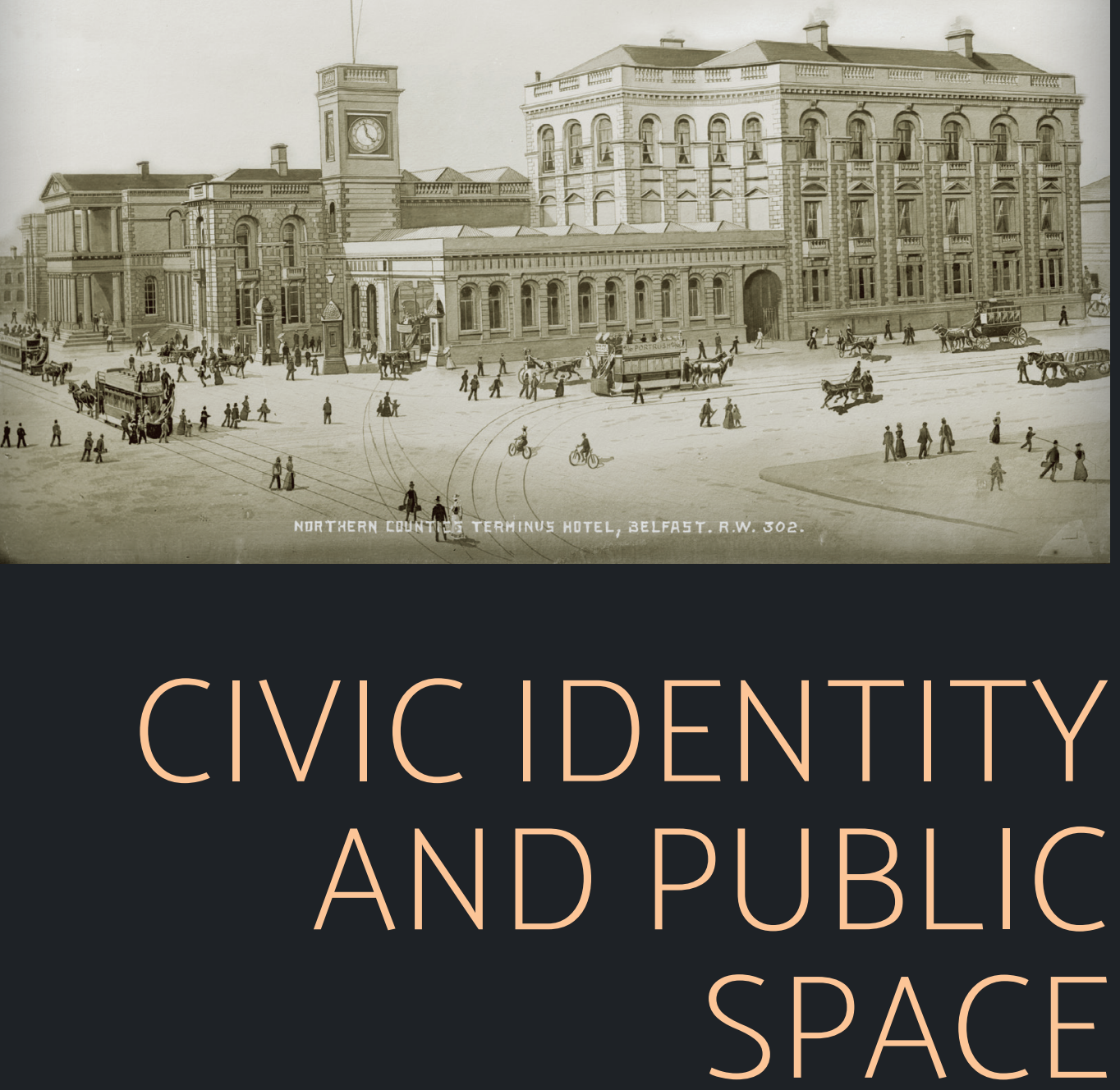

Belfast since 1780 


\section{Civic identity and public space}

\section{MANCHESTER 1824}

Manchester University Press 
Dominic Bryan, S. J. Connolly, and John Nagle - 9781526138316 Downloaded from manchesterhive.com at $\odot 4 / 26 / 2023$ 02:05:39AM 


\title{
Civic identity and public space
}

\author{
Belfast since 1780
}

\section{Dominic Bryan and S. J. Connolly, with John Nagle}


Copyright (C) Dominic Bryan, S. J. Connolly and John Nagle 2019

The right of Dominic Bryan, S. J. Connolly and John Nagle to be identified as the authors of this work has been asserted by them in accordance with the Copyright, Designs and Patents Act 1988.

Published by Manchester University Press

Altrincham Street, Manchester M1 7JA

www.manchesteruniversitypress.co.uk

British Library Cataloguing-in-Publication Data

A catalogue record for this book is available from the British Library

ISBN 9780719086366 hardback

First published 2019

The publisher has no responsibility for the persistence or accuracy of URLs for any external or third-party internet websites referred to in this book, and does not guarantee that any content on such websites is, or will remain, accurate or appropriate.

Typeset in 10.5 on 12.5 pt Bembo Std Regular by Servis Filmsetting Ltd, Stockport, Cheshire 